\title{
Dante's Nose and Publius Ovidius Naso: A Gloss on Inferno 25.45
}

For Kevin Brownlee and Roy Rosenstein*

Io scrittore [l'Ottimo commentatore] udii dire a Dante, che mai rima nol trasse a dire altro che quello ch'avea in suo proponimento; ma ch'elli molte e spesse volte facea li vocaboli dire nelle sue rime altro che quello, ch'erano appo gli dicitori usati di sprimere. (L'ottimo commento 183)

Ovid appears as an ostensibly minor character in one brief but highly charged episode of Dante's Commedia, that of the Pilgrim's and Virgil's encounter with the famous poets who constitute "la bella scola" in Limbo. After Homer and Horace, "Ovidio è 'l terzo, e l'ultimo Lucano" (Inf. 4.90). ${ }^{1}$ Although the author of Dante's primary sourcebook for mythology (the Metamorphoses) receives a scant hemistich of attention and will be mentioned by the name of "Ovidio" only one other time in the Commedia (Inf. 25.97), an authorial interjection near the end of the fourth canto bears on the question of how significant Ovid as an auctor really may be for Dante. In Inferno 4.145-47 the Poet states that his lengthy task keeps him from discoursing as much as he should about the souls he sees:

Io non posso ritrar di tutti a pieno, però che sì mi caccia il lungo tema, che molte volte al fatto il dire vien meno.

The comment "that many times the telling comes short of the fact" challenges the reader to consider, if nothing else, which of the souls in Limbo may have far-reaching significance not only in history but also in Dante's divine poem. What follows is a modest attempt to add to the burgeoning evidence that, for the Commedia, Ovid is as important an authority as Virgil-not only in the Paradiso, where the Metamorphoses strikes some as a nearly ubiquitous palimpsest far eclipsing the Aeneid as a subtext, but also at other crucial junctures of the poem, such as Inferno 25 where the issue of "poetando" (Dante's word in vs. 99) is dramatically addressed. ${ }^{2}$ 
Inferno 25 marks the passage of Dante the Character and his prodding guide Virgil to the seventh bolgia of the eighth circle, the pouch of the transmuting thieves. The canto ends with Vanni Fucci's meteorogically dense and woefully dark prophecy of the expulsion of the White Guelphs from Florence, the event which results in Dante the Poet's exile. The spiteful thief climaxes his speech in the opening terzina of canto 25 with a blasphemous ejaculation directed towards God: a screamed vulgarity and obscene gesture with upraised hands. A serpent immediately silences Vanni by coiling itself tightly around his neck, "come dicesse 'No vo' che più diche'" (6), the first in a series of "silencings" in a canto resonating with poetic voices. A second snake simultaneously wraps around and immobilizes the thief's arms. There follow, in vss. $10-33$ and in quick succession, a bitter invective against Pistoia, the thief's hometown; a parting comment about Vanni's rebelliousness and swift departure from sight; and a description of the arrival and actions of the dragon-bedecked centaur Cacus, who both guards and is punished in this bolgia.

The late Charles Singleton in his commentary states that Dante's Cacus distinguishes itself from that of the Virgilian and Ovidian tradition by being a centaur (rather than a "half-human," as in Aeneid 8.194) and by having a fire-belching dragon on its back (rather than emitting flames from its own mouth, as in Aeneid 8.198-99). He asserts, in addition, that the underlying text for Virgil the Guide's remarks about Cacus (25-33) comes from the eighth book of the Aeneid, 190ff., and he deemphasizes (unfortunately, in my view) Ovid's role in the Dantean narrative. ${ }^{3}$ Ettore Paratore, on the other hand, stresses that when Virgil the Guide tells Cacus's story, some details are decidedly Ovidian; for instance, Cacus is clubbed to death (as in Ovid's Fasti 1.575-78) rather than strangled (as per Virgil's Aeneid). Paratore finds such a correction highly notable "in quanto il ricordo dell'episodio è posto proprio in bocca a Virgilio" (93-94). I agree and believe that such a modification is only a shadow of things to come. Dante the Poet, in other words, makes Virgil the Character replace a detail found in his Latin epic with one traceable to the Ovidian Fasti; this act anticipates, on one hand, Dante the Character's remarkable silencing of his Guide and, on the other, Dante the Poet's replacement of the Aeneid as a subtext in the remainder of this virtuoso canto of metamorphoses. 
In narrative sequence Inferno 25 next records that, as Virgil continues to speak, three spirits (Agnello, Buoso, and Puccio) arrive and ask who the Pilgrim and Guide are and where one of their own number, Cianfa, was left behind (34-43). Virgil, who was previously discoursing, does not have time to respond before Dante silences him with a finger to his lips or, as vs. 45 details the action, with a finger from (Dante's) chin to nose: "mi puosi 'l dito su dal mento al naso" (emphasis added here and later).

This gesture, later found illustrated in Renaissance emblem books as a symbol of silentium (see illustration), never receives an extensive gloss, and commentators almost always follow the same lines. In brief, they emphasize a literal interpretation of the gesture and offer no suggestion that Dante may be engaging in subtle but significant wordplay. ${ }^{4}$ Fourteenth-century commentators find the Pilgrim's silencing action as basically that and little more. L'Ottimo states, quite succinctly, that Dante "fa certo segno a Virgilio, perchè stea attento" (1: 429). Da Buti simply remarks that the finger from chin to nose is "uno atto che l'uomo fa, quando vuole ch'altrui stia cheto et attento, quasi ponendo stanga e chiusura alla bocca" (1: 646). Serravalle, near the beginning of the fifteenth century, writes that the placing of a finger "a mento usque ad nasum" is a "signum optimum ad reddendum aliquem attentum" and that Dante has made a recognizable "actum meditationis" (311). That the act is an important sign or referent I readily agree.

In our own century Natalino Sapegno, in his magisterial commentary, says that "Dante fa segno a Virgilio di tacere, perchè ha udito nominare Cianfa e ha compreso che quel gruppo di dannati dev'essere formato da suoi concittadini" (278). Singleton remarks, "Dante places his forefinger over his lips in the familiar gesture urging silence" (2: 436). More recently, in the Bosco-Reggio commentary, we read that "il gesto, naturalissimo, è per imporre silenzio a Virgilio, perché avendo sentito il nome di Cianfa Donati, Dante comprende trattarsi di Fiorentini" (368). Last of all, the PasquiniQuaglio gloss simply paraphrases the verse as "feci un cenno (mimico) di silenzio" (294). ${ }^{5}$

As early as the fifteenth century, however, at least one classical parallel had been adduced for Inferno 25.45. Christophoro Landino describes the Pilgrim's action as a "cenno pel quale dimostriamo vol- 


\section{In silentium.}

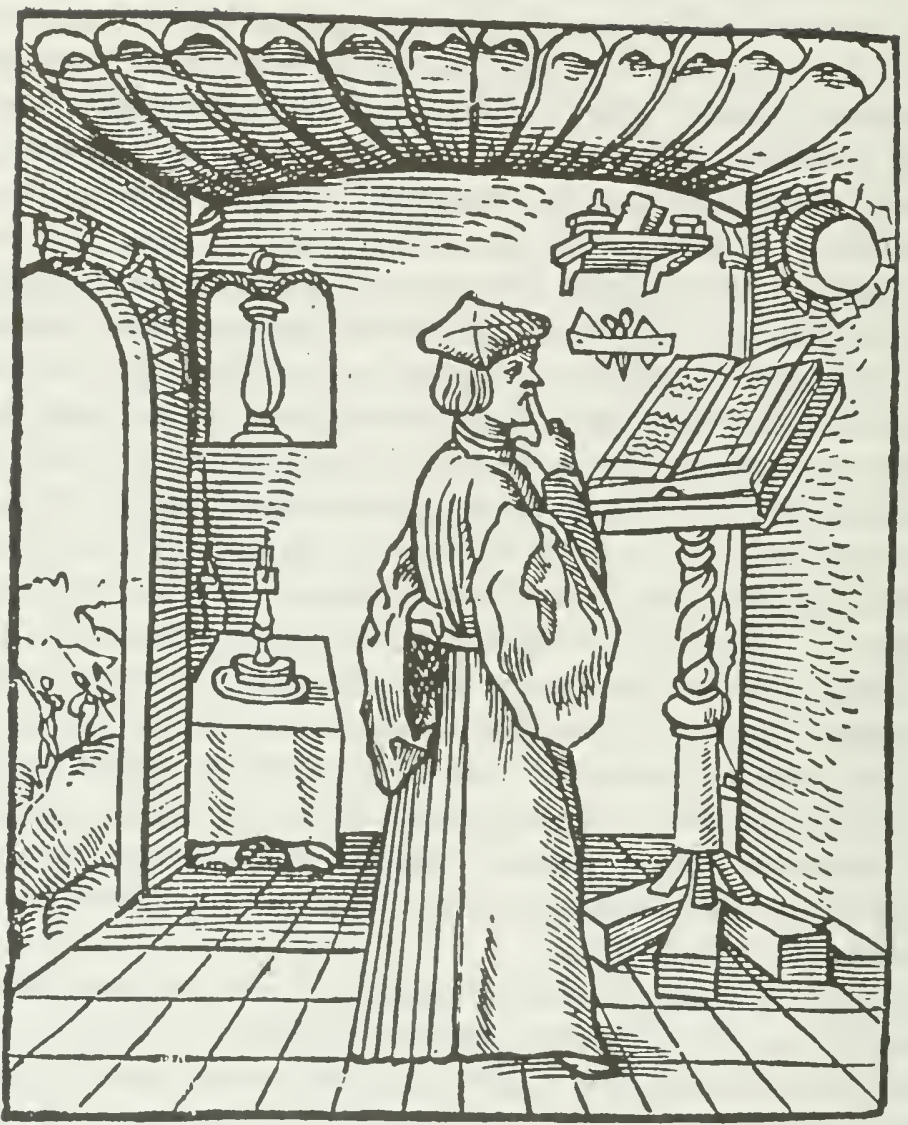

Cum tacet haud quicquam differt fapientibus amès, Sultitic eft index lingua $\tilde{q}_{\text {; }}$ uox q $_{\text {; }}$ fue.

Ergo premat labias, digito'; filentia fignet, Et fefe pharium uertat in Harpocratem.

Illustration from Livret des Emblemes de maistre Andre Alciat mis en rime francoyse e presente a monseigneur Ladmiral de France (sic) (Paris: Chrestien Wechel, 1536). Courtesy of Special Collections, Harold B. Lee Library, Brigham Young University, Provo, Utah. 
ere che si faccia silentio" and cites, as an analogue, Juvenal's "digito compesce labellum" [put your finger to your lip] (Satire 1.160). This citation, although not at all popular in today's commentaries, did find its way into the eighteenth-century commentaries of P. Pompeo Venturi and Baldassare Lombardi, who credits Landino with the original observation (Venturi 313; Lombardi n. pag.). In the midnineteenth century, Tommaseo refers readers to a more likely classical source: Metamorphoses 9.692 (212). Somewhat later in the Ottocento, G. A. Scartazzini, after noting that the verse under discussion is a "gesto naturale di chi chiede silenzio," cites the same Ovidian passage (244). The line in Ovid occurs in the story of Ligdus and his pregnant wife Telethusa. Just before giving birth at midnight, the wife has a dream-vision in which she sees various Egyptian gods, including one who enjoins silence with his finger ("quique premit vocem digitoque silentia suadet"). ${ }^{6}$ This Egyptian god of silence is Harpocrates, whose name appears in other classical poets, such as Catullus (74.4 and 102.7). ${ }^{7}$ The detail perhaps implied in Ovid but nevertheless missing is exactly where Harpocrates places his finger; the Loeb translation of the Metamorphoses suggests that it is "on his lips." Surely this is where Dante the Character places his finger as well, but Dante the Poet insists on wording the description so that the finger's position is from chin to nose ("dal mento al naso"). In a gesture suggestive of an Ovidian passage, Dante's nose and the word naso are both emphasized, the first by having a finger pointed at it and the second by occurring in rhyme position. But what are we to make of this emphasis and how unusual is it?

The word naso appears eight times in the Commedia, although never in the lofty Paradiso. The appearances occur in Inferno 17.75 (when the usurer Reginaldo Scrovegni sticks out "la lingua, come bue che 'l naso lecchi"), 18.108 (when the stench of the flatterers' bolgia is such "che con li occhi e col naso facea zuffa"), 25.45 (when, as noted, Dante silences Virgil by placing “. . . 'l dito su dal mento al naso") and 128 (when the serpent-thief Guercio de' Cavalcanti transforms his superfluous snakeskin into a ". . . naso a la faccia”), and 28.65 (in the description of Pier da Medicina who has ". . 'I naso tronco infin sotto le ciglia"); in Purgatorio 7.113 (when Carlo d'Angiò is referred to periphrastically as ". . . colui dal maschio naso"), 10.62 (when, on the first cornice, Dante refers to his 
senses of sight and smell metonymically as ". . . li occhi e 'l naso"), and 15.7 (when, on the second cornice, the rays of sun strike Dante and Virgil in full face or "... per mezzo 'l naso"). Although in all three occurrences in the Purgatorio the word is in rhyme position, in the Inferno only at 25.45 does the word appear in rhyme, and in the Commedia as a whole only in Inferno 25 does naso appear twice in the same canto, thus ultimately calling more attention to its presence there. While Luciano Graziano in the Enciclopedia dantesca claims that the word is always used "in senso proprio," $\mathrm{I}$ shall argue that its appearance in 25.45 also constitutes a play on Ovid's last name: Publius Ovidius Naso. My reasons for such a gloss are summarized in the six sections which follow.

(1) After Dante the Character silences Virgil the Guide, Dante the Poet completely replaces the Aeneid with subtexts by Ovid and Lucan, though especially by Ovid, for the remainder of this particular canto. (Cf. Inf. 25.58-60 [image of ivy clinging to a tree] and Metam. 4.365 [the same image]; Inf. 25.69-72 [Cianfa the snake and Agnello the man] and Metam. 4.373-79 [Salmacis and Hermaphroditus]; Inf. 25.97 [Cadmus and Arethusa] as well as 25.103-08 [the series of infernal metamorphoses] and Metam. 4.576-80, 586-89 [Cadmus] and 5.572-641 [Arethusa].) The pointing to the naso, therefore, is not only a sign to Virgil the Guide to be silent but also a signal to the reader that (Publius Ovidius) Naso is about to replace Virgil the Poet as auctor for the canto's remaining verses. That naso is meant to capture the reader's attention is attested by the remarkable address which follows immediately in the next tercet (46-48):

Se tu se' or, lettore, a creder lento ciò ch'io dirò, non sarà maraviglia, ché io che 'l vidi, a pena il mi consento.

Not only is the reader addressed in vs. 46 (as "tu" and "lettore") but Dante the Poet is heard in the future tense in vs. 47 ("io dirò") and then the Pilgrim is represented in the past tense in vs. 48 ("vidi"). Perhaps because of this close juxtaposition of the reader to an almost fused Pilgrim-Poet, at least one major commentator has even interpreted the Pilgrim's gesture to Virgil in vs. 45 as an early warning signal to the reader to pay closer attention to narrative action about to transpire. ${ }^{9}$ No commentator has suggested that the gesture invites deeper interpretation than that. But Dante assuredly silences 
Virgil, narratively and textually, so that the reader may discern more clearly the somewhat altered voice of Ovid echoing through the Italian verses. Perhaps what has previously hindered readers from surmising as much is the paradoxical ordering of Ovid to be silent later in the canto, a problem I shall treat next.

(2) The subsequent appearance, in vs. 97, of Ovid's name in unique rhyme position ("Taccia di Cadmo e d'Aretusa Ovidio") makes explicit the Latin poet's importance to this canto of dramatic transformations, as does the canto's subject matter. Dante was acutely aware of the nature of Ovid's chief work and even recorded the title of the Metamorphoses as De Rerum Transmutatione in De monarchia 2.7.10. Certainly in a canto dealing with the "transmutations of things," such as Inferno 25 is, it would be appropriate that naso signify both itself and something else. That Dante is commanding Ovid, too, to be silent ("Taccia ... Ovidio") should not surprise the reader nor undermine my argument. The silencing of Ovid, in contrast to that of Virgil, is not a silencing on the level of narrative action or imagery. Rather it must be recalled that Ovid's silencing is done in a rhetorical fashion (the Latin convention of taceat is documented by Curtius [162-65]) calculated to call attention to his name and that, in point of fact, the rest of the canto resounds with reworked Ovidian passages.

Does Dante, then, only pretend to silence Ovid, or is the classical poet truly silenced in some other sense? The traditional response is that Dante, while incorporating Ovidian (and Lucan) passages, outdoes Ovid (and Lucan) in the number and complexity of transformations and can, therefore, claim to silence the boasts of his predecessors. While such may well be the case, I believe the purported silencing serves two other functions. First, it actually dramatizes the close poetic connection between Ovid and Dante: both recognized that the craft of making verse is very similar to the acts of metamorphosis their poetry describes. Second, the taccia-sequence points to the ultimate difference between classical poetry of transmutation and Christian poetry of conversion and transfiguration. For the reader to recognize these two facts, however, Ovid's name and poetry must be very much in the forefront of the reader's mind-hence the play on Ovid's last name (in truth, a metamorphosis) and the even bolder placement of "Ovidio" in rhyme with "io non lo 'nvidio" (99). (Note, 
too, that "lo 'nvidio" contains the name "Ovidio" within it and that Ovid's name is dismembered and remembered in every "io vidi""Ovidii," Latin genitive for "of Ovid"-as in vss. 48, 112, and 142 of Inferno 25 but also throughout the Commedia.) The Christian poet performed a similar (admittedly inverted but nevertheless effective) act of comparison at the outset of his poem (Inf. 2.32) when he had the Pilgrim claim to be neither Aeneas nor St. Paul (thereby intentionally drawing attention to them); later of course he introduces numerous parallels to make it clear that the Pilgrim is a figure of both Aeneas and St. Paul. (Inferno 2.32 also encourages us to reread the drowning sailor simile of Inferno 1.22-27 in light of Aeneas's shipwreck at the beginning of the Aeneid and also of St. Paul's as detailed in Acts 27.)

(3) Dante knew the cognomen of Ovid and even referred to him as Naso in Epistola 3.4 in a significant phrase referring to the authority of the Latin poet: "Auctoritatem vero Nasonis" (2:534). But even had Dante not indicated in his writings that he was keenly aware of Ovid's last name, it is impossible that he could not have known it given the extraordinary medieval debate over exactly what Naso signified. In Ghisalberti's exhaustive study of medieval biographies of Ovid, the classicist quotes from numerous manuscripts which discuss possible rationales for Naso as a cognomen, from the possibility that it referred only to the size of his nose to the likelihood that it referred symbolically to his wisdom (10-59). ${ }^{10}$ The probability that Dante would have been familiar with and seriously attracted to such discussions is very high. In addition to the large number and widespread locations of the medieval manuscript biographies of Ovid, I need only cite Dante's own Vita Nuova dictum that "names are the consequences of things" ("nomina sunt consequentia rerum") and his own preoccupation with the meanings of names (e.g., Giovanna and Beatrice) from the very beginning of his poetic career. Consider also the care with which he introduces souls whose names are remarkably appropriate, given their punishment or state, from Pier della Vigna (who as a suicide has become precisely a tree) to Costanza (who appears in the lunar sphere ironically because of her lack of constancy).

(4) That Dante is capable of such wordplays as I am arguing for is widely known. In addition to his obvious play on VOM (man) 
in the famous Purgatorio 12.26-63 acrostic, I would cite the more subtle case of Inferno 8.62, where "I fiorentino spirito bizzarro" refers not only to Filippo Argenti but also to the irascible spirit of the Florentine people. But perhaps the most germane example, for my purposes, occurs with the probable double meaning of "omero" in Paradiso 23.65:

\section{Ma chi pensasse il ponderoso tema e l'omero mortal che se ne carca, nol biasmerebbe se sott' esso trema.}

As R. A. Shoaf insightfully points out in his discussion of this passage, the mortal shoulder is "also the mortal Homer ('omero' / 'Omero' - Inf. 4.88), mortal because blind." Shoaf argues that "Dante, with this pun, is at once bold and humble: bold to say he is Homer; humble to assume the mortality implied by Homer's blindness" (70). ${ }^{11}$ Certainly the attitude of both Pilgrim and Poet in Inferno 25 also underscores the boldness of both Dantes-the Pilgrim when he points to his own nose and silences his guide Virgil and the Poet when he commands both Lucan and Ovid to be silent about their prowess as he is about to outperform both of them and to show how metamorphoses may illustrate God's purposes.

A question to entertain but parenthetically at this point: if Dante truly puns on the names of Homer and Ovid, then why does he not perform something similar for Virgil, given that poet's fundamental role in the Commedia? Thanks to a reminder from Professor Rachel Jacoff of Wellesley College, I can refer the interested reader to potential play in the case of Virgil (read Vergil) in Inferno 9.89's reference to the Angelic Messenger's "verghetta" and in Inferno 20.44's allusion to Tiresias's "verga." As Robert Hollander states in his informed discussion of verga, virga, and Virgil in "The Tragedy of Divination in Inferno 20": "[i]n both Inferno 9 and 20 Dante summons up the shade of Virgil's involvement with divination . .." (183). ${ }^{12}$ Given the far-flung medieval speculations on the etymology of Virgil's (or Vergil's) name (not to mention the superstitions tying him to magic), it seems probable that the infernal appearances of verghetta and verga are intended to remind us of the Roman poet's suspected connection with divination. Such wordplays, if intentional, certainly would help prepare the ground for Dante's more pointed pun on Ovid's last name in Inferno 25. 
(5) Dante draws clear attention to two other personages in his poem by reference to their noses. In Purgatorio 7, in the Valley of the Princes episode, Carlo d'Angiò (Charles I of Naples) is referred to as both "maschio naso" (vs. 113) and as "nasuto" (vs. 124), while Philip III of France is called "nasetto" (vs. 103). Because of the medieval exegetical tradition which associated the nose with the gift of discernment (cf. St. Gregory ${ }^{13}$ ), the implications of Dante's referring to two mighty princes by their unusual nasal characteristics are intriguing. Those confined to the Valley of the Princes are rulers whose preoccupation with worldly affairs kept them from more eternally rewarding activities; they must pay in Ante-Purgatory for the skewed perspective they had while alive. Their abnormal noses-one oversized and one undersized-may well reflect iconographically their distorted discernment in spiritual matters. For even if a large nose, as in the case of Charles I, may be interpreted in bono as a sign of sagacity, his lack of earthly wisdom would still make of his "maschio naso" a most ironic statement. The whole nasuto-nasetto episode induces the attentive reader to re-evaluate for symbolic meaning previous noses in the Commedia, especially the Wayfarer's, and raises the distinct possibility that noses and characters may be closely linked in Dante's poetic imagination. ${ }^{14}$

(6) As an elaboration on and extension of my fifth argument, I should like to close by calling attention to Dante's artistic propensity for identifying or describing so many of his characters by reference to some memorable or distinct part of their physical anatomy. Consider, as a few scattered examples in the Inferno alone, the emphasis on Beatrice's eyes (2.55); the hands of Virgil and the Pilgrim as the latter is initiated into the secret things of Hell (3.19); the mouths of Francesca (5.136), Ugolino (33.1), and Satan (34.55); the chest (and brow) of Farinata (10.35) and the petto of Mohammed (28.29); the eyebrows of the sodomites when we first meet them (15.20) and later the private parts of one in particular (15.114); the feet and legs of the simonists (19.23) and later of Judas (34.63) and even Satan (34.90); the tongue and teeth of the ten demons and the arse of their leader (21.137-39); the severed nose, slit throat, and missing ear of Pier da Medicina (28.64-66); and the head and hair of Archbishop Ruggieri (33.2-3).

Why does Dante record so many physical characteristics of souls 
who are, after all, temporarily without bodies (except for the Pilgrim)? Almost all of the anatomical parts alluded to have been discussed in the literature that abounds on Dante, and the most obvious answer is that the medieval Poet/Artist was keenly aware of the iconographic possibilities inherent in poetry, especially allegorical poetry. (He exploits those possibilities quite self-consciously and perhaps even more masterfully in the "visibile parlare" of Purgatorio.) He saw in the various body parts not only a way to make vivid his portrayal of dead souls but also an opportunity to introduce, naturally and in most cases unobtrusively, potent icons or symbols into his poem. When the Poet chooses to highlight one of those physical characteristics, it is especially incumbent upon the reader to ask, "Why this detail and why here?" And so readers have been doing for centuries. The problem with the Pilgrim's gesture to his naso in Inferno 25.45 is that it works so well literally that it has not been heretofore elevated to the status of crux and begged for close scholarly attention. Yet purposefully placed in one of the most plastic and theoretical of cantos, naso requires not only a literal interpretation but also a gloss that at least commences to take into account the larger context of Dante's poetic iconography as well as his dynamic relationship with all his auctores. If my particular reading of naso disturbs, I can only plead as did the Poet before me (Inf. 25.142-44):

Così vid'io la settima zavorra

mutare e trasmutare; e qui mi scusi

la novità se fior la penna abborra.

Brigham Young University

\section{NOTES}

* The author gratefully acknowledges the assistance of all faculty and fellow participants in the first Dartmouth Dante Institute, held June 30 - August 10, 1985, and funded by the National Endowment for the Humanities. In particular, I should like to nole the encouragement and enthusiasm of that year's direclor, Kevin Brownlee. The original idea for the gloss of "naso" as a pun on Ovid's name belongs to DDI participant Roy Rosenstein of The American College in Paris. I listed him as co-author of this article until referees pointed out that the responsibility for writing, arguing, and presenting the gloss must lie with the aclual writer, arguer, and presenter. While accepting full liabilily 
for any shortcomings in the manner in which I have glossed Inferno 25.45, I nevertheless acknowledge my indebtedness to and esteem for Professors Rosenstein and Brownlee by dedicating this commentary to them.

1 All quotations from the Commedia are from the text established by Giorgio Petrocchi as found in the edition and translation of Charles S. Singleton. In my article any quoted translations of the Commedia are also by Singleton.

2 Guido Di Pino, for example, speaks of the "persistenza delle fonti ovidiane le quali, a partire dai canti del paradiso terrestre, si sono sostituite di fatto a quelle virgiliane" (174). A convenient bibliography on Dante and Ovid is located at the end of Ettore Paratore's entry on "Ovidio" in the Enciclopedia dantesca, to which I would add the recent work of two Dartmouth Dante Institute colleagues: Kevin Brownlee, "Ovid's Semele and Dante's Metamorphosis: Paradiso 21-23," and Peter S. Hawkins, "Transfiguring the Text: Ovid, Scripture and the Dynamics of Allusion" and "Dante's Ovid."

3 See Singleton, Inferno 2: Commentary 432: "Dante's monster differs in two striking respects from that of Virgil and Ovid. ... Dante most likely borrowed other details of his description from Virgil (see Aen. 8.193-99). . . . With regard to the mode of Cacus's death, Dante apparently followed not Virgil but Livy. ...."

4 Perhaps the most extended of the literal interpretations is that of Domenico Palmieri, S.I., who says that Dante's action is a "gesto per indicar che si stia zitto: il solo gesto porta con sè l'impronta di comando che però non suol farsi dall'inferiore al superiore, seppure non s'accompagna con qualche tratto del viso, che somigli a preghiera" (444).

5 But see note 9 below.

6 Ovid, Metamorphoses with an English Translation by Frank Justus Miller 2: 52. The verse quoted agrees in all its particulars with that of the more authoritative edition, P. Ovidii Nasonis Metamorphoses, ed. W. S. Anderson.

7 Dante did not know Catullus's poems, where references to Harpocrates are charged with eroticism and where the god's finger is assumed to be in the mouth rather than on the lips. Certainly Alciati's Harpocrates-like emblem of scholarly reflection (see illustration) also suggests that the finger may be at least partially in the mouth. Dante the Pilgrim, in contrast, places his finger from chin to nose and, therefore, on his lips.

8 In Enciclopedia dantesca 4:12, Graziano states that "Il termine [naso] ricorre solo nell'Inferno e nel Purgatorio (una volta nel Detto). ... È sempre in senso proprio." The absence of the word naso in Paradiso stimulates speculation on the role of this word in Dante's poem. I believe naso's disappearance from the last canticle's vocabulary possibily parallels the non-presentation of St. Paul in the same canticle. If there is no St. Paul because Dante the Pilgrim/Poet at the end of the poem symbolizes a new St. Paul (one who has shared in the Pauline raptus and described what the first Paul would not or could not), then perhaps the word naso must necessarily be absent from the poetics of the Paradiso as well. Why? I can only respond with a conjecture. The 
Dante whose nose is pointed to in Inferno 25.45 and the Dante who addresses the reader immediately thereafter become one as the Commedia concludes, and that unificd Dante's portrayal of trasumanar supplants completely the Christian poet's need for any direct reference to the original (and now unquestionably transfigured and surpassed) classical model of metamorphosing poetry: Publius Ovidius Naso. Instead the name will appear only in the highly veiled formula of "io vidi" in Paradiso, and even then it will recall with equal force the Vulgate "vidi" of the Apocalypse.

9 See, for example, A. Momigliano, on Inferno 25.45: "verso che dà l'aria della scena e nel medesimo tempo impone silenzio al lettore e fissa già la sua stupefatta attenzione su quello che seguirà" (188-89, emphasis added). Cf. Pasquini-Quaglio, in the concluding, more extensive comment on the entire canto: "L'improvviso, ma non gratuito, stacco narrativo, nel silenzio intenso, stupito e ammirato dei pellegrini, voluto anzi dal vivo (v. 45), cade sotto le forme di un appello diretto al lettore (vv. 46-48), suona come un campanello d'allarme, squilla come richiamo d'attenzione ad un incredibile spettacolo" (301-02).

10 Ghisalberti writes, "As to the cognomen Naso, not every one agreed in believing it to be an allusion to a physical characteristic and one particularly suited to the poet on account of the moral sagacity which enabled him to smell out the difference between virtue and vice" (27-8). I am indebted to Professor Peter S. Hawkins of the Yale Divinity School for first drawing my attention to Ghisalberti's study and for offering suggestions as to how to improve my own article.

11 For a favorable assessment of Shoaf's somewhat revisionist study, see my "Chaucer and the Three Crowns of Florence (Dante, Petrarch, and Boccaccio): Recent Comparative Scholarship."

12 See Hollander's entire discussion of verga in Ovid. Statius, and Virgil on pp. 176-84, as well as Dante's other uses of verga in Purgatorio 14.102 and 27.80. I here should like to express my appreciation to Professor Hollander for his lectures at the $1985 \mathrm{DDI}$ and for his having read and critiqued an earlier draft of my work.

13 See S. Gregory the Great, vol. 3, pt. 2, bk. 31, sec. 44, on the Song of Solomon $7: 4$, "Thy nose is as the tower, which is in Libanus": "We distinguish also by the nose between odours and foul smells. And what is designated by the nose, but the farseeing discernment of the saints?" See also vol. 2, pt. 3, bk. 15, sect. 37, on Job 21:5, "And lay your finger upon your mouth": "seeing that by our fingers we distinguish things severally, discretion is not unfitly represented by the fingers.... And so the finger is laid to the mouth, when the tongue is bridled by discretion, that by what it utters, it may not fall into the sin of foolishness."

14 One commentator has even proferred a possible connection between Dante's gesture to the nose and another Valley of the Princes event. Giacomo Poletto suggests that "questo luogo [Inf. 25.45] fa, in parte, rammentar l'altro 
dell'Anima nella valletta de' Principi (Purg. 8.9), che l'ascoltar chiedea con mano" (emphasis in the original). Most commentators, however, would likely see a biblical, rather than classical, source in the purgatorial passage cited by Poletto-to wit, Acts 13.16, where St. Paul motions with his hand for silence. (See, for example, Singleton's gloss, Purgatorio 2: Commentary 160.)

\section{WORKS CITED}

Alighieri, Dante. Opere Minori. Ed. P. V. Mengaldo et al. Vol. 2. Milano: Ricciardi, 1979.

Bosco, Umberto, and Giovanni Reggio, eds. La Divina Commedia: Inferno. By Dante Alighieri. Firenze: Le Monnier, 1982.

Brownlee, Kevin. “Ovid's Semele and Dante's Metamorphosis: Paradiso 2123." Modern Language Notes 101 (1986): 147-56. Published in an expanded version, as "Dante's Poetics of Transfiguration: The Case of Ovid." Literature and Belief (1985 [published in 1987]): 13-29.

Curtius, Ernst Robert. European Literature and the Latin Middle Ages. Trans. W. R. Trask. Princeton: Princeton UP, 1973.

Da Buti, Francesco. Commento di Francesco Da Buti sopra La Divina Commedia di Dante Allighieri. Ed. Crescentino Giannini. Vol. 1. Pisa: Nistri, 1858.

Di Pino, Guido. Temi di critica dantesca. Bari: Adriatica, 1973.

Ghisalberti, Fausto. "Mediaeval Biographies of Ovid." Journal of the Warburg and Courtauld Institutes 9 (1946): 10-59.

Graziano, Luciano. “Naso.” Enciclopedia dantesca. 6 vols. Roma: Istituto della Enciclopedia Italiana, 1970-78.

Gregory the Great. Morals on the Book of Job ... Translated. Oxford: J. H. Parker, 1850.

Hawkins, Peter S. "Transfiguring the Text: Ovid, Scripture and the Dynamics of Allusion." Stanford Italian Review 5.2 (1985): 115-39.

"Dante's Ovid." Literature and Belief (1985 [published in 1987]):

$1-12$.

Hollander, Robert. Studies in Dante. Ravenna: Longo, 1980.

Landino, Christophoro. Comento di Christophoro Landino fiorentino sopra la Comedia di Dante Alighieri poeta fiorentino. Brescia: Boninus de Boninis, 1487.

Lombardi, Baldassare. La Divina Commedia, novamente corretta spiegata $e$ difesa da F. B. L. M. C. Roma: Fulgoni, 1791.

$L$ 'Ottimo commento della Divina Commedia: Testo inedito d'un contemporaneo di Dante citato dagli Accademici della Crusca. Vol. 1. Pisa: Niccolò Capurro, 1827.

Momigliano, A. La Divina Commedia commentata da A. Momigliano. Firenze: Sansoni, 1951.

Ovid. Metamorphoses with an English Translation by Frank Justus Miller. 2 vols. Cambridge, MA: Harvard UP, 1946.

P. Ovidii Nasonis Metamorphoses. Ed. W. S. Anderson. Leipzig: 
Teubner, 1977.

Palmieri, Domenico, S. I. Commento alla Divina Commedia di Dante Alighieri. Vol. 1. Prato: Giachetti, 1898.

Paratore, Ettore. Nuovi saggi danteschi. Roma: Signorelli, 1973.

" "Ovidio." Enciclopedia dantesca. 6 vols. Roma: 1stituto della Enciclopedia Italiana, 1973.

Pasquini, Emilio and Antonio Quaglio, eds. Commedia: Inferno. Milano: Garzanti, 1982.

Poletto, Giacomo. La Divina Commedia di Dantc Alighieri con commento del Prof. Giacomo Poletto. Roma: Descléc, Lefebvre, 1894.

Sapegno, Natalino, ed. La Divina Commedia. Vol. 1. Firenze: La Nuova Italia, 1968.

Scartazzini, G. A. La Divina Commedia di Dante Alighieri riveduta nel testo e commentata da G. A. Scartazzini. 3rd ed. Milano: Hoepli, 1899.

De Serravalle, Frater lohannes. Fratris Iohannis de Serravalle Translatio et comentum totius libri Dantis Aldigherii cum textu italico. Prato: Giachetti, 1891.

Shoaf, R. A. Dante, Chaucer, and the Currency of the Word: Money, Images, and Reference in Late Medieval Poetry. Norman, OK: Pilgrim Books, 1983.

Singleton, Charles S. The Divine Comedy of Dante Alighieri. 6 vols. Princeton: Princeton UP, 1970-75.

Sowell, Madison U. "Chaucer and the Three Crowns of Florence (Dante, Petrarch, and Boccacio): Recent Comparative Scholarship." Journal of the Rocky Mountain Medieval and Renaissance Association 6 (1985): 173-82.

Tommaseo, Niccolò. Commedia di Dante Alighieri con ragionamenti e note di Niccolo Tommaseo. Milano: Rejna, 1854.

Venturi, P. Pompeo. La Divina Commedia di Dante Alighieri . . col commento del P. Pompeo Venturi. Firenze: Ciardetti, 1821. 